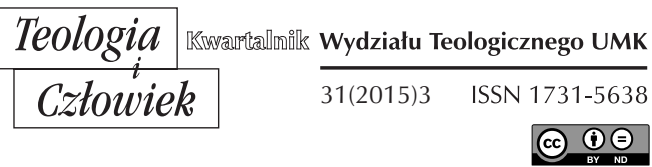

JANUSZ ADAM FRYKOWSKI*

TOMASZÓW LUBELSKI

\title{
Z DZIEJÓW DEKANATU UNICKIEGO W TYSZOWCACH. PARAFIA PW. ŚW. MIKOKAJA W DUBIE W XVIII WIEKU
}

DOI: http://dx.doi.org/10.12775/TiCz.2015.039

\section{WPROWADZENIE}

Wieś Dub, siedziba nieistniejącej już dzisiaj parafii p.w. św. Mikołaja, swoimi korzeniami sięga co najmniej pierwszej połowy XV wieku. Jak podaje Wasyli Słobodian w swojej pracy o cerkwiach diecezji chełmskiej, pierwsza cerkiew w Dubie istniała już w 1430 roku, a sama miejscowość musi być starsza niż świątynia ${ }^{1}$. Kolejna informacja źródłowa dotycząca tej miejscowości pochodzi z 1442 roku, kiedy jej właścicielem był kniaź litewski - Hurko Lubartowicz². Wówczas Dub organizacyjnie był zwią-

* Janusz Adam Frykowski jest doktorem nauk humanistycznych w zakresie historii nowożytnej Polski, członkiem Tomaszowskiego Towarzystwa Regionalnego im. dra Janusza Petera oraz dyrektorem Zespołu Szkół Nr 1 im. Bartosza Głowackiego w Tomaszowie Lubelskim.

1 W. Słobodian, podając tę datę, powołuje się na pracę I. Крипякевича, Церкви Холмщини и Пидяшшя, Холм 1944, s. 45-49. Zob.: В. Слободян, Церкви Холмскоі епархї, Львів 2005, s. 188.

2 A. Janeczek, Osadnictwo pogranicza polsko-ruskiego. Województwo bełskie od schyłku XIV do początku XVII w., Warszawa 1993, s. 27. 
zany z księstwem bełskim, a po jego wcieleniu do Korony znalazł się w granicach nowo utworzonego województwa bełskiego. Zmiana przynależności Duba nastąpiła wraz z pierwszym rozbiorem i aż do 1809 roku znajdował się on pod panowaniem austriackim. W tymże roku w wyniku powiększenia Księstwa Warszawskiego Dub znalazł się w jego granicach, a stan taki utrzymał się do końca wojen napoleońskich. Kolejna zmiana przynależności Duba miała miejsce w 1815 roku, ponieważ miejscowość znalazła się w obrębie utworzonego na kongresie wiedeńskim, Królestwa Polskiego, zależnego od Cesarstwa Rosyjskiego ${ }^{3}$.

Wiadomo, że tereny Rusi Czerwonej pierwotnie stanowiły teren działalności Cerkwi prawosławnej, która jako pierwsza na tym terenie stworzyła struktury i prowadziła chrystianizację․ Do 8 października 1596 roku funkcjonowała tam eparchia chełmska, a następnie - w wyniku zawartej unii w Brześciu - chełmska diecezja unicka5 ${ }^{5}$ Oddziaływanie

${ }^{3}$ Więcej na temat historii tej wsi zob.: A. Kupiec-Niedźwiedź, J. Niedźwiedź, Dzieje miejscowości gminy Komarów Osada powiat zamojski, Komarów-Zamość 2003, s. 30-35.

${ }^{4}$ Najprawdopodobniej na początku omawiane tereny podlegały eparchii kijowskiej, a następnie zostały podporządkowane powołanej przed 1086 r. katedrze we Włodzimierzu Wołyńskim. Stan taki przetrwał do I połowy XIII w., kiedy to książę Daniel Halicki podporządkował je organizacyjnie nowo utworzonemu biskupstwu w Uhrowsku. Kariera Uhrowska jako siedziby biskupa była bardzo krótka, ponieważ tenże książę już około 1240 r. przeniósł biskupstwo do Chełma. Powody tej decyzji nie są do końca znane. Być może było to spowodowane jakimiś działaniami militarnymi, w wyniku których Uhrowsk uległ zniszczeniu, o czym mogą świadczyć odkryte ślady pożaru. Zob.: A. Poppe, Kościót i państwo na Rusi w XI wieku, Warszawa 1968, s. 178; A. Gil, Prawosławna eparchia chetmska do 1596 r., Lublin-Chełm, 1999, s. 61; L. Bieńkowski, Diecezja prawosławna, w: Encyklopedia katolicka, red. R. Łukaszyk, L. Bieńkowski, F. Gryglewicz, Lublin 1988, t. III, kol. 132; J. Mazuryk, S. Panyszko, O. Ostapiuk, Badania archeologiczne latopisiwego Uhrowieska, „Archiwum Polski Środkowowschodniej”, 1998, nr 3, s. 175-182.

${ }^{5}$ O unii brzeskiej zob.: E. Likowski, Unia brzeska, Warszawa 1907; H. Dylągowa, Dzieje unii brzeskiej (1596-1918), Warszawa 1996; Czterechsetlecie zawarcia Unii Brzeskiej 1596-1996: materiały $z$ sesji naukowej zorganizowanej $w$ Toruniu $w$ dniach 28-29 listopada 1996 r., red. S. Alexandrowicz i T. Kempa, Toruń 1998; Dziedzictwo Unii Brzeskiej, red. R. Dobrowolski, M. Zemło, Lublin-Supraśl 2012; Unia brzeska 1596 r. Geneza i skutki. Katalog wystawy, Toruń 1997; Unia brzeska. Materiały z radomskiego sympozjum, red. A. Hejda, Radom 1998; Unia brzeska, geneza, dzieje i konsekwencje w kulturze narodów słowiańskich, red. R. Łużny, F. Ziejka, A. Kępiński, Kraków 1994; Брестская уния 1596 2. и общественно-политическая борьба на Украине и в Белоруссии в коние XVI-первой 
Kościoła łacińskiego na omawianym obszarze ma późniejszą metrykę niż wpływ Kościoła ruskiego i wiąże się z początkami chełmskiej diecezji katolickiej, która powstała w połowie XIV wieku ${ }^{6}$. W związku z tym na ukształtowanie świadomości religijnej mieszkańców Duba miało wpływ oddziaływanie zarówno prawosławnej eparchii chełmskiej (po 1596 roku unickiej), jak i chełmskiej diecezji katolickiej obrządku łacińskiego. Dlatego też możemy mieć pewność, że wieś zamieszkiwała ludność obydwu wyznań, a po 1596 roku - zarówno dwóch wyznań, również dwóch obrządków ${ }^{7}$.

W wyniku rozbiorów unici znaleźli się w granicach zaboru rosyjskiego i austriackiego. W zaborze austriackim byli nazywani grekokatolikami i traktowani na równi z katolikami obrządku rzymskiego ${ }^{8}$.

половине XVII в., ч. 1, Брестская уния 1596 г. Исторические причины, отв. ред. Б. Флоря, Москва 1996; Брестская уния 1596 г. и общественно-политическая борьба на Украине и в Белоруссиив коние XVI-первой половине XVII в., ч. 2, Брестская уния 1596 г. Исторические последствия события, отв ред. Б. Флоря, Москва 1996; М. Дмитриев, Брестская уния в исследованиях польских и российских историков, w: Российско-польские научные связи в XIX-XX вв., редкол. В. Волков, Л. Марней, Б. Носов, Москва 2003; М. Дмитриев, Между Римом а Царьградом, Генезис брестской иерковной унии 1595-1596 гг., Москва 2003 [Труды Исторического Факультета МГУ, 22, ред. С. Карпов-Серия II, Исторические Исследования, 7]; А. Турилов, Б. Флоря, К вопросу об исторической альтернативе Брестской унии, w: Брестская уния 1596 г. и общественно-политическая борьба на Украине и в Белоруссии в коние XVI-первой половине XVII в., ч. 2, Брестская уния 1596 г. Исторические последствия события, отв. ред. Б. Флоря, Москва 1996.

${ }^{6}$ Wraz z zajęciem ziemi bełskiej i chełmskiej oraz przyłączeniem jej do Królestwa Polskiego, król Kazimierz Wielki zaczął starać się o utworzenie łacińskiej organizacji kościelnej ze stolicą biskupią, by w ten sposób ugruntować katolicyzm na tych terenach. Na prośbę króla papież Innocenty VI bullą z 20 maja 1359 r. mianował biskupem chełmskim Tomasza z Sienna. Bulla ta ustanowiła metropolię w Haliczu i trzy biskupstwa: w Przemyślu, Chełmie i Włodzimierzu Wołyńskim. Zob.: B. Kumor, Granice metropolii i diecezji polskich (968-1939), „Archiwa, Biblioteki i Muzea Kościelne”, 1969, nr 19, s. 336; T. Trajdos, Kościół katolicki na ziemiach ruskich Korony i Litwy za panowania Władysława II Jagietly (1386-1434), t. I, Wrocław 1983, s. 215.

7 A. Gil, Prawosławna eparchia chełmska do 1596 r., s. 167; A. Mironowicz, Struktura organizacyjna Kościoła prawosławnego w Polsce $w$ X-XVIII wieku, w: Kościót prawosławny w Polsce dawniej i dziś, red. L. Adamczuk, A. Mironowicz, Warszawa 1993, s. 48-58; L. Bieńkowski, Diecezja prawosławna, kol. 132.

${ }^{8}$ Dla Kościoła unickiego nazwę "greckokatolicki” wprowadziła w 1774 r. ce- 
Oba obrządki objęte zostały systemem rządów józefińskich, polegającym na bardzo silnym podporządkowaniu Kościoła państwu. Zdecydowanie gorzej przedstawiała się sytuacja unitów w zaborze rosyjskim. Zaborca uważał, że unię zawarto niezgodnie z prawem i traktował unitów jako odłączonych przemocą od Kościoła prawosławnego. Planowa akcja nawracania unitów zaczęła się już po II rozbiorze. Jej efektem w Cesarstwie Rosyjskim było przyłączenie Kościoła unickiego do Cerkwi prawosławnej w 1839 roku. Zniesienie unii w Rosji i włączenie jej do prawosławia było przedostatnim aktem rozprawy z Kościołem greckokatolickim. Ostateczne jego istnienie w zaborze rosyjskim zostało zakończone w 1875 roku, gdy cesarz Aleksander II ogłosił włączenie unitów do Kościoła prawosławnego. Artykuł przedstawia dzieje nieistniejącej już parafii unickiej p.w. św. Mikołaja w Dubie, w czasie funkcjonowania jej w strukturach dekanatu tyszowieckiego. Zmiana przynależności dekanalnej parafii w Dubie nastąpiła pod koniec XVIII stulecia, kiedy miejscowość ta znajdowała się w zaborze austriackim. Wówczas w konsekwencji tzw. reform józefińskich, parafia ta została podporządkowana dziekanowi w Grabowcu' ${ }^{9}$ W 1866 roku władze carskie dokonały ponownego podziału dekanalnego, dostosowując granice dekanatów do granic powiatów, skutkiem czego parafia znalazła się w obrębie dekanatu tomaszowskiego. Oznaczało to, że z parafii leżących na terenie danego powiatu utworzono dekanat przyjmujący nazwę od miasta powiatowego. $\mathrm{W}$ ten sposób powstało 12 nowych dekanatów, a wśród nich tomaszowski, liczący 30 parafii, który przetrwał do 1875 roku, czyli do czasu kasacji unii ${ }^{10}$.

Należy zaznaczyć, że dzieje parafii w XVII wieku, w przeciwieństwie do XVIII wieku, przedstawione są dość ogólnikowo ze względu na niedostateczną ilość materiałów źródłowych. Przyczyną tych niedostatków był fakt, że rzadko sporządzano wówczas protokoły wizytacji, albo też nie zachowały się one do naszych czasów. Na ubogi zasób źródeł miało wpływ wiele czynników. Można do nich zaliczyć straty i zniszczenia

sarzowa Maria Teresa. Zob.: H. Dylągowa, Unia brzeska. Geneza - dzieje - zagłada, w: Czterechsetlecie zawarcia unii brzeskiej 1596-1996, s. 19.

9 W. Kołbuk, Duchowieństwo unickie w Królestwie Polskim 1835-1875, Lublin 1992, s. 15-17.

${ }^{10}$ W. Kołbuk, Kościoły wschodnie na ziemiach dawnej Rzeczypospolitej 1772-1914, s. 102 . 
spowodowane działaniami wojennymi oraz klęskami żywiołowymi ${ }^{11}$. Nie bez znaczenia była także niechęć księży Kościoła wschodniego do stałego dokumentowania jego organizacji, swojej działalności, gdyż dominowała wówczas ustna kultura prawna. Taki stan rzeczy nie pozwala na pełne odtworzenie działalności parafii.

Artykuł niniejszy oparto na bogatej bazie źródłowej znajdującej się w Archiwum Państwowym w Lublinie, a w szczególności w zespole Chełmskiego Konsystorza Greckokatolickiego. Podstawowymi źródłami do przedmiotowego artykułu są protokoły wizytacji parafii. Ich znaczenie wynika z faktu, że przedstawiają stan i potrzeby kościoła parafialnego, wielkość beneficjum plebana, spisy inwentarza kościoła, stan cmentarza, a także budynków gospodarczych. Omówienie wizytacji jako źródła historycznego oraz literatury do tego zagadnienia można znaleźć u Stanisława Litaka, Hieronima Edwarda Wyczawskiego i Stanisława Librowskiego ${ }^{12}$.

Bardzo pomocne w przygotowaniu artykułu były prace dotyczące szeroko rozumianej działalności Kościoła wschodniego w Polsce. Mimo upływu czasu z opracowań dotyczących tego zagadnienia ogromną wartość posiadają prace Ludomira Bieńkowskiego ${ }^{13}$. Przeprowadził on szeroką kwerendę archiwalną i zaprezentował pełną panoramę dziejów Cerkwi unickiej od strony instytucji kościelnych, jak również organizacji terytorialnej. Do dzisiaj niezastąpione jest mistrzowskie opracowanie przez

${ }^{11} \mathrm{Na}$ temat zniszczeń w diecezji chełmskiej w wyniku wojen z połowy XVII w. zob.: A. Gil, Chełmska Diecezja Unicka w okresie rządów biskupa Jakuba Suszy (1649-1687), w: Sztuka sakralna i duchowość pogranicza polsko-ukraińskiego na Lubelszczyźnie (Materiały z Międzynarodowej Konferencji „Sztuka Sakralna Pogranicza”, Lublin 13-15.10.2005 r.), red. S. Batruch, R. Zilinko, Lublin 2005, s. 61-66.

12 S. Litak, Akta wizytacyjne parafii z XVI-XVIII wieku jako źródło historyczne, „Zeszyty Naukowe KUL”, 1962, t. V, nr 3, s. 43; H. E. Wyczawski, Wprowadzenie do studiów w archiwach kościelnych, Warszawa 1956; S. Librowski, Wizytacje diecezji wrocławskiej, cz. 1, Wizytacje diecezji kujawsko-pomorskiej, t. 1, Opracowanie archiwalno-źródłoznawcze, z. 1, Wstęp ogólny, „Archiwa, Biblioteki i Muzea Kościelne”, 1964, nr 8, s. 5-186.

${ }^{13}$ L. Bieńkowski, Kultura intelektualna $w$ kręgu Kościoła Wschodniego w XVII-XVIII wieku, w: Dzieje Lubelszczyzny, t. 6, Między Wschodem a Zachodem, cz. 1, Warszawa 1989, s. 107-125; tenże, Mozaika religijno-kulturalna Rzeczypospolitej w XVII i XVIII w., w: Uniwersalizm i swoistość kultury polskiej, red. J. Kłoczowski, t. 1, Lublin 1989, s. 241-270; tenże, Oświecenie i katastrofa rozbiorów (II poł. XVIII wieku), w: Chrześcijaństwo w Polsce, red. J. Kłoczowski, Lublin 1992, s. 275-373. 
niego dziejów, a ponadto organizacji Kościoła wschodniego XV-XVIII wieku na terenie Rzeczypospolitej ${ }^{14}$. Kontynuatorem pracy Bieńkowskiego jest Witold Kołbuk, autor wielu artykułów i monografii traktujących w ogromnej części o sytuacji unii i unitów w XVIII-XIX wieku ${ }^{15}$. Najbardziej przydatna w niniejszym artykule okazała się jego praca o strukturach organizacyjnych Kościołów wschodnich na terenie Rzeczypospolitej w XVIII-XX wieku, która została oparta na bardzo bogatej podstawie źródłowej, zarówno archiwalnej, jak i drukowanej, oraz wyjątkowo obszernej, kompetentnie dobranej literaturze. Istotne dla poruszanych $\mathrm{w}$ tej pracy zagadnień są publikacje Andrzeja Gila dotyczące funkcjonowania eparchii chełmskiej i unickiej diecezji chełmskiej ${ }^{16}$. W artykule wykorzystano także prace Hanny Dylągowej ${ }^{17}$ czy Janusza Lewandowskiego ${ }^{18}$. Nie do przecenienia są także dwie prace Pawła Sygowskiego, poruszające problematykę wizytacji parafii unickich w diecezji chełmskiej w XVIII stuleciu ${ }^{19}$.

${ }^{14}$ L. Bieńkowski, Organizacja Kościoła Wschodniego w Polsce w: Kościół w Polsce, red. J. Kłoczowski, t. II, Kraków 1970, s. 781-1050.

15 W. Kołbuk, Kościoły wschodnie na ziemiach dawnej Rzeczypospolitej1772-1914, Lublin 1992; tenże, Duchowieństwo unickie w Królestwie Polskim 1835-1875, Lublin 1992; tenże, Kościoły wschodnie w Rzeczypospolitej około 1772 roku, Lublin 1998; tenże, Ustawy $i$ statuty unickich bractw cerkiewnych, w: Unia brzeska. Geneza, dzieje i konsekwencje w kulturze narodów słowiańskich, red. R. Łużny, Kraków 1994, s. 329-336.

16 A. Gil, Prawosławna Eparchia Chetmska do 1596 r.; tenże, Chetmska diecezja unicka 1596-1810. Dzieje i organizacja. Studia i materiały z dziejów chrześcijaństwa wschodniego w Rzeczpospolitej, Lublin 2005; tenże, Chełmskie diecezje obrzadku wschodniego. Zagadnienia organizacji terytorialnej w XVII i XVIII wieku, w: Polska-Ukraina. 1000 lat sąsiedztwa, red. S. Stępień, Przemyśl 2000, t. 5, s. 29-61.

${ }_{17}$ H. Dylągowa, Kościót unicki na ziemiach Rzeczypospolitej (1596-1918). Zarys problematyki, „Przegląd Wschodni”, 1992/93, nr 2, z. 2 (6), s. 257-287; Taż, Unia Brzeska i unici w Królestwie Polskim, Warszawa 1989; Taż, Unia brzeska - dzieje - zagłada, w: Czterechsetlecie zawarcia unii brzeskiej 1596-1996, s. 11-24.

${ }_{18}$ J. Lewandowski, Na pograniczu. Polityka władz państwowych wobec unitów Podlasia i Chełmszczyzny 1772-1875, Lublin 1996; tenże, $Z$ dziejów unickiej diecezji chetmskiej w latach 1790-1804, „Rocznik Chełmski”, 1995, t. 1, s. 51-63.

19 P. Sygowski, Unicka diecezja chetmska $w$ protokołach wizytacyjnych biskupa Maksymiliana Ryłty z lat 1759-1762, w: Polska-Ukraina 1000 lat sasiedztwa, t. 5, s. 233-285; tenże, Wizytacja cerkwi unickiej diecezji chetmskiej przeprowadzonej w latach 1720-1725 przez biskupa chetmskiego i bełskiego Józefa Lewickiego, w: „Studia archiwalne”, Lublin 2007, t. 2, s. 199-232. 


\section{POWSTANIE PARAFIl}

Parafia jest podstawową jednostką w strukturze organizacyjnej Kościoła i jednocześnie najbardziej trwałym elementem krajobrazu kulturowego ${ }^{20}$. Życie lokalnej społeczności było w całym omawianym okresie nierozerwalnie związane z parafią, która pełniła w obrębie tej społeczności o wiele więcej funkcji niż współcześnie. Kontakt wiernych z Kościołem był jednym z zasadniczych czynników integrujących lokalną społeczność. Przymus parafialny, legitymizujący minimalny zakres obowiązujących w tych kontaktach norm, podkreślał i utrwalał więzi tworzące się naturalnie poprzez związek z Kościołem, pogłębiając tym samym proces konsolidacji zbiorowości zamieszkującej parafię ${ }^{21}$. Pierwotna chrystianizacja terenów późniejszej parafii w Dubie była związana z ekspansją państwa ruskiego na ziemie nadbużańskie, a pierwsza wzmianka o cerkwi w tej wsi, jak już wcześniej wspomniano, pochodzi z 1430 roku. Kolejna informacja potwierdzająca funkcjonowanie tam parafii prawosławnej pochodzi z 1531 roku i poświadczona jest także dla reszty XVI stulecia ${ }^{22}$. Potwierdzenie źródłowe istnienia cerkwi w Dubie wcale nie oznacza początku funkcjonowania tam parafii prawosławnej. Wiadomo, że dla określenia czasu powstania kościołów parafialnych najbardziej wiarygodne są dokumenty fundacyjne i erekcyjne. Pierwszy z nich zapowiadał zaistnienie stanu prawnego, drugi stan ten tworzył ${ }^{23}$. W przypadku omawianej cer-

${ }^{20}$ M. Nowodworski, Parafia, w: Encyklopedia kościelna, red. M. Nowodworski, Warszawa 1892, s. 200; J. Koziej, Parafia, w: Encyklopedia katolicka, red. E. Gigilewicz, Lublin 2010, kol. 1324-1326.

${ }^{21}$ E. Wiśniowski, Rozwój sieci parafialnej w prepozyturze wiślickiej w średniowieczu. Studium geograficzno-historyczne, Warszawa 1965, s. 9; tenże, Rozwój organizacji parafialnej $w$ Polsce do czasów reformacji, w: Kościół w Polsce, t. I, s. 237-238; tenże, Kościół parafialny $i$ jego funkcje społeczne $w$ średniowiecznej Polsce, „Studia Theologica Varsaviensia", 1969, nr 7, s. 207.

22 A. Gil, Prawosławna eparchia chetmska do 1596 r., s. 227; Źródła dziejowe, t. XVIII, cz. 1, Polska XVI wieku pod względem geograficzno-statystycznym, t. VII, cz. 1, Ziemie Ruskie. Ruś Czerwona, opisane przez Aleksandra Jabłonowskiego, Warszawa 1902, s. 184.

${ }^{23}$ Zasadniczą funkcją dokumentu fundacyjnego było określenie materialnych podstaw funkcjonowania świątyni, bez których nie mogłaby ona spełniać swoich zadań. Zob.: W. Wójcik, Fundacja, w: Encyklopedia katolicka, red. L. Bieńkowski, Lublin 1989, t. V, kol. 760-761. 
kwi brak jest tych dokumentów, co nie pozwala na określenie czasu jej powstania.

Zdecydowanie inaczej wygląda sytuacja powołania parafii łacińskiej w tej wsi. Wiadomo, że kościół w Dubie został wystawiony w 1543 roku przez jej właściciela - Dobrogosta Drohiczyńskiego (Dubieńskiego), a parafia erygowana 21 maja 1544 roku. Pierwsza łacińska wspólnota wiernych w Dubie istniała krótko, ponieważ ok. 1560 roku, świątynia ta została przejęta na zbór kalwiński ${ }^{24}$.

Nie wiadomo kiedy utworzona została parafia prawosławna i nie ustalono dotychczas, jak wyglądało wprowadzanie unii w tej wspólnocie. Można się jedynie domyślać, że mogło mieć podobny przebieg jak w siedzibie dekanatu - Tyszowcach, gdzie pomiędzy zwolennikami unii, a jej przeciwnikami doszło do zamieszek. Wydarzenia te miały tak bardzo gwałtowny przebieg, że doprowadziły do siłowego odbierania świątyń, niszczenia wyposażenia, a nawet napadów na kapłanów i wiernych obu stron ${ }^{25}$.

Parafia w Dubie przez pierwszy okres swojego funkcjonowania znajdowała się w strukturach protopopii w Tyszowcach ${ }^{26}$. Dokładna data utworzenia tego dekanatu nie jest znana. Ustalono tylko, że w 1573 roku funkcjonowała tam rola protoprezbitera prawosławnego. Można więc sądzić, że struktura terytorialna i organizacyjna dekanatu tyszowieckiego po przyjęciu unii nie uległa poważniejszym zmianom, podobnie jak w przypadku całej Cerkwi ${ }^{27}$. Jak już wcześniej wspomniano, zmiana przynależności do dekanatu w Grabowcu miała miejsce w czasie, gdy parafia znalazła się w granicach monarchii austriackiej.

${ }^{24}$ E. Kupiec-Niedźwiedź, J. Niedźwiedź, dz. cyt., s. 30.

25 A. Gil, Chetmska diecezja unicka 1596-1810, s. 73-74.

${ }^{26}$ Protopopia (protoprezbiteria), odpowiednik dekanatu w Kościele łacińskim, na czele której stał protopop (protoprezbiter), była jednostką stanowiącą pośrednie ogniwo administracji diecezjalnej. Duchowny ten sprawował funkcję administracyjno-kontrolną i sądowniczą, lecz tę ostatnią utracił w XVIII wieku. Zob.: E. Likowski, Dzieje Kościoła unickiego na Litwie i Rusi w XVIII i XIX wieku uważane głównie ze względu na przyczyny jego upadku, Warszawa 1906, t. 1, s. 38-59; G. Chruscewicz, Istorija zamojskago sobora (1720 goda), Wilno 1880, s. 155-267; A. Gil, I. Skoczylas, Kościoły wschodnie w państwie polsko-litewskim w procesie przemian i adaptacji: Metropolia kijowska w latach 1458-1795, Lublin-Lwów 2014, s. 325-342.

27 Archiwum Główne Akt Dawnych w Warszawie (dalej: AGAD), Archiwum Skarbu Koronnego (dalej: ASK), sygn. 36, k. 307v. 


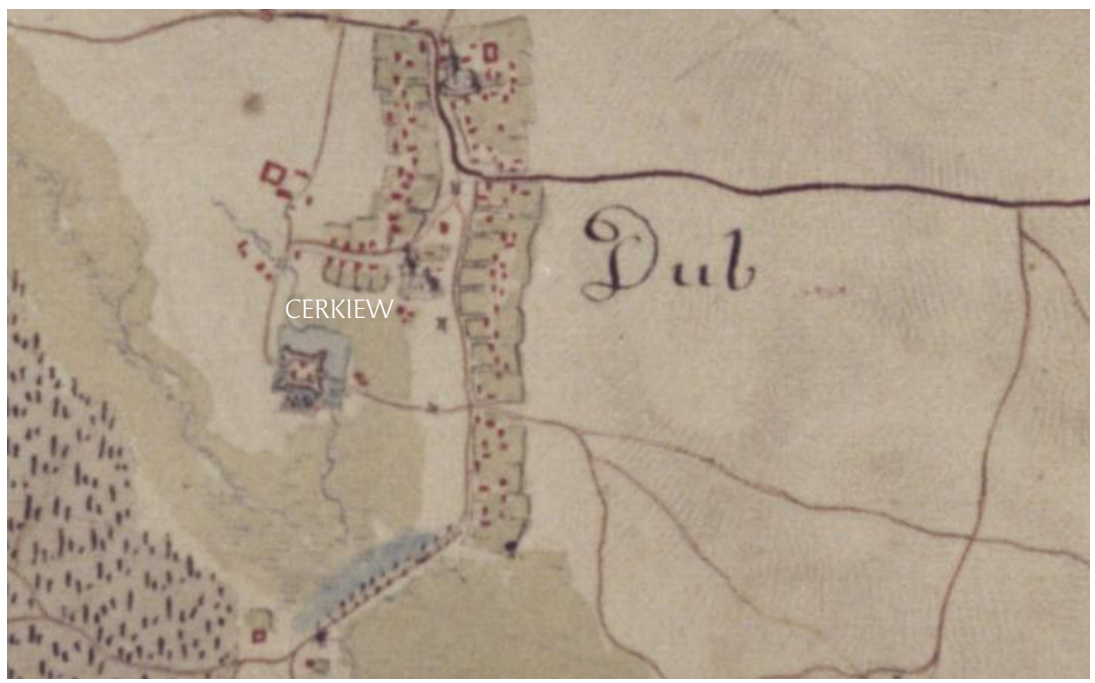

Rys. 1. Dub. Wycinek z mapy F. von Miega, Karte des Königsreiches Galizien und Lodomerien, 1:28800, 1779-1782

Źródło: Kriegsarchiv Wiedeń, rps. B. IX a, k. 390.

Powyższa ilustracja jest wycinkiem wielkoskalowej mapy sporządzonej w latach 1779-1783 przez majora Friedricha von Miega dla Królestwa Galicji i Lodomerii oraz terytorium Rzeczypospolitej, które zostało włączone do Austrii w wyniku wydarzeń z 1770 r. oraz pierwszego rozbioru w 1772 r. $\mathrm{Z}$ analizy ryciny wynika, że pod koniec XVIII wieku Dub był dość rozległą wsią posiadającą cechy zabudowy zarówno ulicówki, jak i rzędówki ${ }^{28}$. $\mathrm{Na}$ ilustracji zaznaczono wyraźnie położenie cerkwi i kościoła.

\section{CERKIEW PARAFIALNA}

Pierwsza, źródłowa informacja o budynku cerkwi w Dubie pochodzi z protokołu wizytacji z 1720 roku $^{29}$. Niestety, poza ogólnikowym

${ }^{28}$ Ulicówka - typ wsi jednodrożnej o zwartej zabudowie rozmieszczonej po obydwu stronach drogi, położoną w dolinie wśród niewielkich obszarów leśnych. Rzędówka - typ wsi, charakteryzujący się luźną zabudową wzdłuż drogi, najczęściej po jej jednej stronie i prostopadle do drogi biegnącymi szerokimi pasami pól, których szerokość odpowiada szerokości zagrody gospodarskiej znajdującej się po drugiej stronie drogi.

29 Archiwum Państwowe w Lublinie (dalej: APL), Chełmski Konsystorz Greckokatolicki (dalej: ChKGK), sygn. 101, k. 51v. 
stwierdzeniem, że „ścianach i dachach reperacji potrzebuje”, nie ma żadnych informacji o wyglądzie świątyni. Podobnie przedstawia się sytuacja w przypadku dzwonnicy, o której wiadomo jedynie, że istniała i że zawieszone na niej były 4 dzwony. Mimo że w źródle nie podano, z jakiego materiału zbudowana była cerkiew, można być pewnym, że była budowlą drewnianą, pokrytą gontem lub słomą, gdyż tak stawiano najczęściej budowle sakralne nie tylko we wsiach, ale także i w miastach ${ }^{30}$. Kolejna wizytacja, przeprowadzona przez biskupa Maksymiliana Ryłło 6 października 1760 roku, dostarcza zdecydowanie więcej informacji o tej świątyni ${ }^{31}$. Hierarcha informuje, że do świątyni „w ścianach i dachach stara”, prowadziły drzwi osadzone na żelaznych zawiasach, zamykane na zewnętrzny zamek. Światła dziennego do wnętrza doprowadzały okna w drewnianych ramach.

Przy cerkwi znajdowała się dzwonnica z 4 dzwonami i ogrodzony cmentarz. Biskup nie był zadowolony z ogrodzenia nekropolii, ponieważ nakazał parochowi „cmentarz razem z gromadą lepiej ogrodzić”.

Wyznacznikiem kondycji i zamożności domu Bożego, oprócz okazałości bryły świątyni i jej uposażenia, jest także zasobność w liczne przedmioty służące kultowi religijnemu. Ich obecność poświadcza sakralny charakter miejsca, bowiem są one niezbędne przy wielu obrzędach. Wśród sprzętu kościelnego możemy wyróżnić naczynia liturgiczne, wyposażenie ołtarza oraz szaty liturgiczne, czyli oficjalny strój dla celebransów i ich pomocników.

Naczynia liturgiczne, zwane także argenteriami, używane są w chrześcijaństwie głównie do sprawowania mszy św., ale także poza nią. Służą najczęściej do przechowywania artykułów niezbędnych do mszy: wody, wina, opłatków, hostii konsekrowanych czy do wykonywania czynności związanych z odprawianiem mszy (np. obmycie rąk - lavabo). Są to m.in.: kielich, patena, ampułki, lawaterz (lavabo), cyborium (puszka), vasculum, monstrancja, melchizedek oraz kustodia. Wykonane są z różnych materiałów, np. ampułki są najczęściej szklane, zaś kielichy oraz puszki metalowe i złote (pozłacane). Wszystkie naczynia, w któ-

${ }^{30}$ J. G ó r a k, Kościoły drewniane Zamojszczyzny, Zamość 1986; tenże, Dawne cerkwie drewniane w dawnym województwie zamojskim, Zamość 1984.

31 APL, ChKGK, sygn. 110, s. 388. 
rych trzyma się Ciało i Krew Pańską, są złote lub pozłacane w miejscu kontaktu z nią.

Pierwszych danych o naczyniach liturgicznych w omawianej cerkwi dostarcza protokół wizytacji z 1720 roku $^{32}$. Według spisu zamieszczonego w tym źródle na wyposażeniu świątyni była drewniana o spiżowym korpusie puszka pro conservando venerabili, srebrny i wewnątrz pozłacany kielich, patena i gwiazda, drugi kielich z pateną cynową i mosiężna łyżecz$\mathrm{ka}^{33}$. Osobną grupę utensyliów stanowiły tekstylne podstawki i przekrycia stanowiące tzw. szaty kielicha, które w tej cerkwi były reprezentowane przez 2 korporały ${ }^{34}$. Dalsze informacje w tym zakresie przedstawione są także w protokole wizytacji z $1732 \mathrm{roku}^{35}$. Z analizy tego źródła wynika, że liczba utensyliów nie uległa zmianie, natomiast poprawiła się jakość puszki, która została pozłocona. Ponadto przybył jeszcze 1 korporał. Ostatnich ujawnionych danych w tym zakresie dostarcza protokół wizy-

32 Tamże, sygn. 101, k. 51v.

33 Puszka - naczynie w kształcie kielicha do przechowywania chleba eucharystycznego. Gwiazda (asteriskos, zwiezdica) - są to dwa metalowe łuki, które po połączeniu tworzą formę krzyża greckiego. Symbolizuje gwiazdę betlejemską, która doprowadziła do Chrystusa trzech mędrców ze Wschodu. Stawia się ją na dyskosie (symbolu żłóbka). Drugą funkcją gwiazdy jest oddzielenie leżącego na dyskosie chleba eucharystycznego od pokrowców, którymi nakrywa się dyskos. Łyżeczka - zwana w księgach liturgicznych lawyną - służy do udzielania wiernym Komunii Świętej. Powinna być wykonana z tego samego materiału, co kielich i dyskos. Symbolizuje kleszcze, którymi Serafin wziął żarzący się węgiel z ołtarza Bożego i oczyścił nim usta proroka Izajasza. Podobnie kapłan przy pomocy łyżeczki udziela wiernym Komunii Świętej i oczyszcza ich grzechy. „Przenajświętsze Ciało i Krew Pańska, niejako żarzący się węgiel oczyszcza ciało i duszę tych, którzy wierzą w naukę Chrystusa" - są to słowa modlitwy na poświęcenie łyżeczki liturgicznej. Patena (dyskos) - jest to złoty, pozłocony lub wykonany z innego drogocennego metalu mały talerzyk, na którym kapłan kładzie chleb eucharystyczny (prosforę). Dyskos powinien mieć nóżkę, która pomaga przenosić chleb eucharystyczny ze stołu ofiarnego (proskomydyinyka) na Święty Ołtarz. Podczas obrzędu przygotowania darów ofiarnych symbolizuje żłobek betlejemski, jak również pojednanie i zjednoczenie wszystkich ludzi wierzących w Jezusa. Zob.: A. Markunas, T. Uczitiel, Popularny słownik sakaralizmów polskich i ukraińskich, Poznań 2001, s. 15, 59, 79, 92.

${ }^{34}$ Korporał - lniane płótno, na którym stoi kielich i patena z hostią w czasie mszy świętej. Zob.: Tamże, s. 53.

35 APL, ChKGK, sygn. 103, k. 152v. 
tacji z 1760 roku $^{36}$. Jak pokazuje to źródło, w stosunku do poprzedniej wizytacji nastąpiły widoczne zmiany jakościowe i ilościowe wśród utensyliów. Widoczny jest wpływ synodu zamojskiego i pojawienie się wśród argenteriów monstrancji ${ }^{37}$. Naczynie wykonano ze srebra i pozłocono, wieńczyła je blaszana koronka, w której był srebrny krzyżyk. Wizytator zastał także nową srebrną puszkę z nakrywką, którą zakupił dziekan tyszowiecki. Znajdowały się także srebrne dwa kielichy i dwie pateny. Pierwszy komplet był cały pozłocony, jednak ze względu na użytkowanie „już wytarty”, w związku z czym w dekrecie po wizytacji biskup nakazał pozłocić te naczynia. Drugi komplet był złocony tylko wewnątrz (intus). Z dekretu powizytacyjnego wynika, że biskup nakazał także zakupić srebrną łyżeczkę i melchizedech w monstrancji pozłocić.

Wyposażenie ołtarza stanowiły różnorodne przedmioty uświetniające przebieg nabożeństwa, do których zalicza się krzyże, świeczniki, zasłonki czy też obrusy. Przedmioty te wykonane są z różnorodnych materiałów, począwszy od metali szlachetnych, poprzez cynę, mosiądz, drewno, a skończywszy na różnego rodzaju tekstyliach.

Pierwszych danych o tzw. wyposażeniu ołtarza w tej cerkwi dostarcza protokół jej wizytacji z 1720 roku $^{38}$. Niestety, w źródle tym nie

36 Tamże, sygn. 110 , s. $388-389$.

37 Odbyty w 1720 r. synod w Zamościu, wprowadził nowe i usankcjonował wprowadzone wcześniej zmiany, upodabniające obrządek unicki do łacińskiego. Wówczas to ustanowiono uroczystość Bożego Ciała, codzienne msze święte, jednolitą administrację sakramentów, wprowadzono monstrancje do wystawiania na ołtarzu oraz miejsce do przechowywania Najświętszego Sakramentu, tzw. tabernakulum. W czasie nabożeństw zaczęto używać organów, a podczas procesji chorągwi, sztandarów, feretronów i dzwonków. Ponadto odprawiano drogę krzyżową, gorzkie żale, odmawiano różaniec i koronki. Unici do cerkwi wstawili ławki, konfesjonały oraz boczne ołtarze. Wprowadzone zmiany spowodowały, że cerkwie wznoszone w drugiej połowie XVIII w. były najczęściej pozbawione ikonostasu. Kapłanom nakazano głosić kazania i wykładać katechizm, pozwolono także nosić takie same sutanny, jak księżom katolickim oraz golić zarost. Synod zobowiązał też kapłanów do posyłania synów na naukę do szkół. Wprowadzono wówczas także dalsze ograniczenia władzy dziekanów, która sprowadzała się odtąd jedynie do sprawowania przez nich funkcji administracyjno-kontrolnych. Zob.: E. Likowski, Dzieje Kościoła unickiego..., s. 38-59; G. Chruscewicz, dz. cyt., s. 155-267; A. Gil, I. Skoczylas, dz. cyt., s. 325-342; D. Ciołka, Latynizacja Kościoła unickiego w Rzeczypospolitej po synodzie zamojskim, Białystok 2014.

38 APL, ChKGK, sygn. 100, k. 51v-54. 
ma wzmianek o ołtarzach w świątyni, jest natomiast wiadomość, że w cerkwi było 2 antyminsy, co może świadczyć, że mogły tam być nawet 2 stoły ofiarne ${ }^{39}$. Z utensyliów metalowych wymienione są 2 trybularze, jeden „srebrny porządny”, a drugi mosiężny ${ }^{40}$. Dalej wymieniona jest para mosiężnych lichtarzy, cynowa tabliczka, 2 dzwonki „do elewacji” (do celebracji mszy) oraz cynowy krzyż na „sedesie” (postumencie). Dużą grupę stanowiły przedmioty tekstylne, wśród których było 7 antependiów z harasu w różnym kolorze, 2 jedwabne zasłonki i 30 „obrusów i chust białych różnych"41. W źródle tym wspomniana jest także lampa określona jako „tepiłowa”, niestety, nie stwierdzono, co oznacza to określenie. Kolejne informacje o utensyliach pochodzą z protokołu wizytacji z $1732 \mathrm{roku}^{42}$. W stosunku do poprzedniego spisu przybyły 4 srebrne korony, 2 sznury korali i pozłacany medalik (zapewne wota dziękczynne), „sukienka na Najświętszej Pannie szarszedronowa czerwona z galonem szychowym" i jeszcze jedna jedwabna zasłonka ${ }^{43}$. Ubył natomiast srebrny trybularz

39 Antymins (gr. „zamiast ołtarza”) - płócienny lub lniany kwadratowy obrus z przedstawieniem Chrystusa złożonego w grobie, postaciami czterech ewangelistów oraz zaszytą cząstką relikwii na pamiątkę celebrowania Eucharystii na grobach męczenników przez pierwszych chrześcijan. Bez antyminsu poświęconego przez biskupa nie wolno sprawować liturgii. Po czytaniu Ewangelii rozkłada się go na prestole i na nim sprawowana jest Eucharystia. Zob.: E. Smykowska, Liturgia prawosławna. Mały słownik, Warszawa 2004, s. 10.

40 Trybularz - kadzielnica. Zob. A. Markunas, T. Uczitiel, dz. cyt., s. 113.

${ }^{41}$ Antependium - dekoracyjna zasłona przedniej części mensy ołtarzowej, z przedstawieniem scen z życia Chrystusa, Matki Bożej lub świętych. Zob.: B. M. Seniuk, dz. cyt., s. 336. Arus (harus) - tkanina wełniana lub półwełniana, różnej szerokości, używana w Polsce XVII-XVIII w. Zob. I. Turnau, Słownik ubiorów. Tkaniny, wyroby pozatkackie, skóry, broń i klejnoty oraz barwy znane w Polsce od średniowiecza do początku XIX w., Warszawa 1999, s. 16.

${ }^{42}$ APL, ChKGK, sygn. 103, k. 152v-153.

${ }^{43}$ Korony ślubne - podczas udzielania sakramentu małżeństwa kapłan nakłada na głowy nowożeńców korony, które są zewnętrznym, widzialnym znakiem tego sakramentu, symbolem zaślubin Chrystusa z Kościołem, mężczyzna uosabia Chrystusa, kobieta - Kościół. Zob.: E. Smykowska, Zwyczaje i obrzędy prawosławne. Mały słownik, Warszawa 2008, s. 31. Galon - wyrób pasamoniczy w formie gładko lub wzorzyście tkanej, rzadziej płóciennej taśmy z nitek jedwabnych, bawełnianych i metalowych. Szarszedron - półwełniana tkanina o jedwabnej osnowie, tkana splotem płóciennym. Szych - przędza lniana lub bawełniana okręcona paseczkiem miedzianym posrebrzanym lub pozłacanym. 
i cynowa tabliczka. W przypadku lampy podano, że wykonana była z mosiądzu (być może była to lampa wcześniej określona jako „tepiłowa”). Ostatnich XVIII-wiecznych informacji w tym zakresie dostarcza protokół wizytacji z $1760 \mathrm{roku}^{44}$. Po raz pierwszy jest mowa o ołtarzu w kontekście uwagi w dekrecie powizytacyjnym: „Za wielki ołtarz żadne białogłowy nie powinny wchodzić, a gdy mają jakąś potrzebę, to mają zatrzymać się przed carskim wrotami i powiadać parochowi nie wchodząc za ołtarz". Po takiej informacji jest pewne, że w tej cerkwi znajdował się co najmniej 1 ołtarz, chociaż nie można wykluczyć występowania także bocznych. W tymże dekrecie pojawia się także zalecenie wstawienia zamka do cyborium, co stwierdza jego występowanie w świątyni ${ }^{45}$. Występowanie ołtarza i tabernakulum jest kolejnym, wyraźnym przejawem latynizacji cerkwi w Dubie. W stanie pozostałych utensyliów zaszły tylko niewielkie zmiany, a mianowicie przybyła jeszcze jedna para mosiężnych lichtarzy i kolejna zasłonka.

Niezbędnym elementem wyposażenia każdej świątyni są także księgi liturgiczne, według których w kościele odprawia się nabożeństwa oraz sprawuje sakramenty. Dzięki księgom sprawowana liturgia jest jednolita i zgodna z wyznawaną wiarą. Obok ksiąg liturgicznych występują tzw. książki pobożne, które zawierają modlitwy i nabożeństwa prywatne. Ze względu na technikę zapisu księgi dzieliły się na drukowane i pisane ręcznie; ten drugi typ występował jeszcze w XIX wieku. Ze względu na wielkość występowały one najczęściej w czterech formatach, tj. in folio, in quarto, in sexto oraz in octavo, czyli w formacie arkusza, połowy arkusza i jego części. Miejscem wydania tych ksiąg mógł być Lwów, Wilno, Supraśl, Uniew lub Poczajów, gdyż tylko w tych miastach funkcjonowały drukarnie unickie ${ }^{46}$.

Warstwa pokrycia była różnej grubości, stąd dwa rodzaje szychu - prosty i gruby, obficiej złocony lub srebrzony. Potocznie tkanina jedwabna lub półjedwabna, przerabiana. Zob.: I. Turnau, dz. cyt., s. 60, 175, 182.

${ }^{44}$ APL, ChKGK, sygn. 110, s. 388-389.

${ }^{45}$ Cyborium (tabernakulum) - puszka do przechowywania konsekrowanej hostii. Zob. A. Markunas, T. Uczitiel, dz. cyt., s. 24.

${ }^{46}$ Drukarnia przy klasztorze bazyliańskim w Uniewie działała w latach 1648-1770, przy klasztorze bazyliańskim Trójcy Świętej w Wilnie - w latach 1628-1839, natomiast we Lwowie znajdowały się dwie drukarnie: Józefa Szmulińskiego, działająca 
Tabela nr 1. Księgi cerkiewne w Dubie w XVIII wieku

\begin{tabular}{|c|c|c|c|}
\hline \multirow{2}{*}{ Nazwa księgi } & \multicolumn{3}{|c|}{ Data odnotowania w źródłach } \\
\hline & 1720 & 1731 & 1761 \\
\hline Ewangelia & $\mathrm{x}$ & $\mathrm{x}$ & $\mathrm{x}$ \\
\hline Służebnik $^{\mathrm{a}}$ & $\mathrm{x}$ & $2 \mathrm{x}$ & $\mathrm{x}$ \\
\hline Trefołoj $^{\mathrm{b}}$ & $\mathrm{x}$ & $\mathrm{x}$ & $\mathrm{x}$ \\
\hline Triod cwietnaja $^{c}$ & $\mathrm{x}$ & $\mathrm{x}$ & $\mathrm{x}$ \\
\hline Triod postnaja & $\mathrm{x}$ & $\mathrm{x}$ & $\mathrm{x}$ \\
\hline Apostoł $^{\mathrm{d}}$ & $\mathrm{x}$ & $\mathrm{x}$ & $\mathrm{x}$ \\
\hline Psałterz $^{\mathrm{e}}$ & $\mathrm{x}$ & $\mathrm{x}$ & $\mathrm{x}$ \\
\hline Trebnik $^{\mathrm{f}}$ & $2 \mathrm{x}$ & $2 \mathrm{x}$ & - \\
\hline Czasosłów $^{g}$ & - & $\mathrm{x}$ & $\mathrm{x}$ \\
\hline Szestodniewiec $^{\mathrm{h}}$ & $\mathrm{x}$ & $\mathrm{x}$ & $\mathrm{x}$ \\
\hline Półustaw $^{\mathrm{i}}$ & $\mathrm{x}$ & - & - \\
\hline Minieja $^{j}$ & $\mathrm{x}$ & $\mathrm{x}$ & $\mathrm{x}$ \\
\hline Irmołoj $^{\mathrm{k}}$ & $\mathrm{x}$ & $\mathrm{x}$ & $\mathrm{x}$ \\
\hline Klucz do kazań & - & $\mathrm{x}$ & $\mathrm{x}$ \\
\hline
\end{tabular}

Źródła: APL, ChKGK, sygn. 101, k. 52; sygn. 103, k. 152v-153; sygn. 110, s. 388-389.

Objaśnienia: a - Służebnik - księga przeznaczona dla diakonów i prezbiterów Kościoła wschodniego, zawierająca porządek nabożeństw i krótkie uwagi dla chóru lub psalmisty. Zob.: A. Markunas, T. Uczitiel, dz. cyt., s. 100; b - Trefołoj (minieja prazdnicznaja) - książka cerkiewna zawierająca wybór tekstów formularzy świątecznych większych świąt wyjętych z minei miesięcznej. Zob.: O. Narbutt, dz. cyt., s. 128; c - Triod postnaja i cwietnaja - ogólna nazwa księgi liturgicznej w Kościele wschodnim, zawierającej porządek nabożeństw świat ruchomych. Postnaja zawiera części zmienne liturgii godzin okresu przedpościa i Wielkiego Postu do Wielkiej Soboty. Cwietnaja zawiera zmienne części liturgii godzin okresu paschalnego do Niedzieli Wszystkich Świętych. Zob.: B. Pańczuk, Księgi liturgiczne, w: Encyklopedia katolicka, red. A. Szostek, E. Ziemann, R. Sawa, K. Góźdź, J. Herbut, S. Olczak, R. Popowski, Lublin 2004, t. X, kol. 110; d - Apostoł - księga zawierająca dzieje i listy apostołów. Zob.: A. Markunas, T. Uczitiel, dz. cyt., s. 13; e - Psałterz - część księgi Liturgii zawierająca psalmy, podzielona na różne dni i pory dnia w cyklu czterotygodniowym. Zob.: Tamże, s. 92; f - Trebnik - zbiór modlitw okazjonalnych i rytuałów towarzyszących posługom religijnym w Kościele wschodnim. Zawiera porządek udzielania sakramentów, sakramentaliów, błogosławieństw. Zob.: Tamże, s. 112; g - Czasosłow - księga niezbędna dla psalmisty oraz chóru cerkiewnego przy odprawianiu codziennych nabożeństw; zawiera teksty niezmienne i zmienne odnoszące się do liturgii cyklu tygodniowego lub rocznego z podaniem kalendarza liturgicznego. Zob.: Tamże, s. 25; h - Szestodniewiec - zwany oktoichem. Zob.: Z. Jaroszewicz, Księgi staroobrzędowców w klasztorze w Wojnowie w zbiorach Muzeum Warmii i Mazur, „Rocznik Olsztyński”, 1989, t. 16, s. 239; i - Typikon (ustaw) - zawiera szczegółowy opis wszystkich nabożeństw na cały rok liturgiczny i metody korzystania z wszystkich pozostałych ksiąg liturgicznych. Zob. A. Markunas, T. Uczitiel, dz. cyt., s. 113; j Minieja - księga liturgiczna, zawierająca porządek służby bożej jako liturgii godzin, jako liturgii mszalnej w odniesieniu do tekstów zmiennych dla świąt nieruchomych cyklu rocznego. Zob. O. Narbutt, dz. cyt., s. 59; k - Irmołoj - księga liturgiczna bizantyjsko-słowiańska zawierająca przeznaczone do śpiewu liturgicznego teksty zmiennych części porządku służby bożej jako liturgii mszalnej i jako liturgii godzin. Na treść irmołogionu składają się teksty irmosów wybrane z oktoicha, obu triod i minei. Zob.: Tamże, s. 63.

w latach 1687-1688 i przy klasztorze bazyliańskim - w latach 1700-1708. Drukarnia przy klasztorze bazyliańskim (ławra poczajowska) działała w latach 1733-1830, przy klasztorze bazyliańskim w Supraślu - w latach 1695-1804 z przerwą na lata 1697-1711. Zob.: O. Narbutt, Historia i typologia ksiag liturgicznych bizantyńsko-słowiańskich. Zagadnienie identyfikacji według kryterium treściowego, Warszawa 1979, s. 41. 
Dla parafii w Dubie, w badanym okresie, informacje o księgach stwierdzono we wszystkich protokołach wizytacji. Zarówno wielkość, jak i różnorodność księgozbioru w tej parafii nie odbiegała znacząco od sytuacji w parafiach dekanatu tyszowieckiego, ale i pobliskiego tomaszowskiego ${ }^{47}$. W każdym $\mathrm{z}$ tych wykazów wizytator najwięcej miejsca poświęcił ewangelii, szczegółowo opisując jej wygląd. Z analizy opisu wynika, że między 1720 a 1760 rokiem była to ta sama księga - egzemplarz drukowany, który do 1732 roku był oprawiony niebieskim aksamitem, a następnie srebrem. Okładki zdobiło 9 srebrnych „sztuk”, a zamykano je srebrnymi klauzurkami i przyklauzurkami ${ }^{48}$. O innych księgach posiadamy zdecydowanie mniej informacji. Co do służebników - wiadomo, że wydane były w Wilnie i Lwowie. Wśród trebników był wielki i mały, natomiast półustaw i czasosłow określano jako wielkie. W zdecydowanej większości księgi były drukowane, poza irmołogionem, który napisano ręcznie. Ponadto w dekrecie powizytacyjnym biskup M. Ryłło nakazał parochowi nabyć w drukarni unickiej trebnik.

Szaty liturgiczne, zwane także paramentami (od „paramenty” szaty ozdobne), to rodzaj okrycia stosowanego w czasie liturgii, mającego na celu określenie i zaznaczenie funkcji osoby je noszącej. Początkowo nie różniły się one od odzieży świeckiej używanej od święta. Różnice pojawiły się dopiero w VII-IX wieku. Używa się go dla pokazania pewnych różnic między kapłanem i służbą liturgiczną a wiernymi, a także dlatego, że każda z nich coś symbolizuje. W tradycji bizantyjskiej wyróżnia się pięć kolorów szat liturgicznych ${ }^{49}$.

${ }^{47}$ Zob.: J.A. Frykowski, Dzieje parafii unickiej w Pienianach, „Radzyński Rocznik Humanistyczny”, 2014, nr 12, s. 23-49; tenże, Z dziejów Diecezji Unickiej w Chełmie. Parafia unicka $w$ Łaszczowie do 1863 r., „Rocznik Chełmski”, 2013, t. 17, s. 53-69; tenże, Parafia unicka $w$ Podlodowie w XVII-XVIII wieku, „Rocznik Tomaszowski”, 2013, nr 1(2), s. 33-43; tenże, Parafie prawosławne i unickie w Tyszowcach XVI-XVIII wieku, „Radzyński Rocznik Humanistyczny”, 2012, t. 10, s. 33-48; tenże, Parafia unicka w Rachaniach do 1811 roku, „Annales UMCS”, 2012, t. 67, nr 2, s. 7-24; tenże, Dzieje parafii unickiej w Jarczowie w XVIII wieku, „Nasza Przeszłość”, 2014, nr 122, s. 67-85.

${ }^{48}$ Klauzurki - dekoracyjne klamry-zamki na księgach cerkiewnych. Przytwierdzone do okładek metalowe płytki, zdobione ornamentyką, nieraz filigranem i kamieniami szlachetnymi, łączone zawiaskowym, metalowym, lub metalowo-skórzanym zatrzaskiem. Zob.: B.M. Seniuk, dz. cyt., s. 340.

${ }^{49}$ Biały (srebrny) - symbolizujący światłość Bożej Chwały i oświecenie umy- 
Pierwsze informacje o szatach liturgicznych w omawianej cerkwi pochodzą z protokołu wizytacji z 1720 roku $^{50}$. Ze źródła wynika, że paroch miał do swojej dyspozycji 4 kompletne aparaty i 3 alby ${ }^{51}$. Pierwszy z nich został uszyty z materiału sajowego w kolorze czerwonym, drugi z czarnego kamlotu, przedostatni $\mathrm{z}$ niebieskiego harasu, a ostatni w kolorze zielonym był kitajkowy ${ }^{52}$. Jak pokazuje kolejny wykaz szat z 1732 roku, liczba alb nie zmieniła się, natomiast przybył kolejny aparat kitajkowy ${ }^{53}$. Przy wyliczeniu aparatów pojawia się także wzmianka, że wszystkie posiadały patrachele i narękawki ${ }^{54}$. Ostatnie dane o paramentach pochodzą

słu, używany podczas największych świąt, np. Paschy - Zmartwychwstania Pańskiego; żółty (złoty) - symbolizujący aniołów, używany najczęściej w ciągu roku liturgicznego; czerwony - symbolizujący szatę, w którą był ubrany Chrystus przed Piłatem, a także krew męczenników; czarny - używany szczególnie w Wielkim Poście oraz na pogrzebach; niebieski - używany podczas świąt maryjnych; zielony - używany raz w roku na Zesłanie Ducha Świętego. Zob.: B. Snela, Kolory liturgiczne, w: Encyklopedia katolicka, red. B. Migut, A. Szostek, R. Sawa, K. Gwóźdź, J. Herbut, S. Olczak, R. Popowski, Lublin 2002, t. 9, kol. 385-386.

50 APL, ChKGK, sygn. 101, k. 51v.

${ }^{51}$ Aparat - komplet przyborów i szat potrzebnych przy odprawianiu ceremonii.

Zob.: I. Turnau, dz. cyt., s. 15.

${ }^{52}$ Saja - początkowo wełniana, później półbawełniana tkanina z gorszej przędzy, w apreturze poddawana gotowaniu w naprężeniu, farbowana i kalandrowana dla połysku. Wyrabiana od XIV w. w Europie Zach. i importowana do Polski. Od XVI w. produkowana w Gdańsku i na Śląsku z gorszych gatunków wełny, jako tańsza wyparła import. Kamlot (czamlet, kamlet) - cienka, rzadka tkanina z szorstkiej wełny czesankowej gorszego gatunku, tkana splotem płóciennym. W średniowieczu robiona była $z$ wełny koziej i wielbłądziej. Później, na Zachodzie tkano ją czasem na osnowie jedwabnej, lnianej, a nawet konopnej. W Polsce znana od XIV w. Arus (harus) - tkanina wełniana lub półwełniana, różnej szerokości, używana w Polsce XVII-XVIII w. Kitajka - cienka, dość gęsta, gładka tkanina jedwabna o splocie płóciennym, jednobarwna lub mieniąca się. Najprostsza i najpospolitsza z tkanin jedwabnych. Wyrabiana na Wschodzie, w XVII w. importowana do Polski z Turcji. Zob.: Tamże, s. 16, 79, 87, 160.

53 APL, ChKGK, sygn. 103, k. 152v.

${ }^{54}$ Epitrachylion - stuła kapłana wschodniego, ważna szata liturgiczna prezbitera; podwójnie złożony orarion - długa wąska wstęga zapięta na lewym ramieniu diakona wschodniego, o końcach zwisających z przodu i z tyłu, diakoński ozdobiony krzyżykami; Epimanikion (poruczy) - narękawek przy dłoniach ułatwiający wygodne odprawianie liturgii św. Zob.: A. Markunas, T. Uczitiel, dz. cyt., s. 33, 75, 84. 
z protokołu wizytacji z 1760 roku $^{55}$. Jak wykazuje źródło, liczba szat zwiększyła się do 5 aparatów i 4 alb. Spośród wcześniej wymienionych aparatów ubył kitajkowy zielony, przybył natomiast jeszcze kitajkowy czerwony i półparterowy ${ }^{56}$.

\section{UPOSAŻENIE DUCHOWIEŃSTWA}

Fundamentem uposażenia duchowieństwa parafialnego były majątki beneficjalne, w skład których wchodziły różnego rodzaju dobra nieruchome i prawa majątkowe. Podstawowe źródło dochodów parochów unickich stanowiły gospodarstwa rolne, przy czym należy pamiętać, że nie były one zbyt okazałe. W porównaniu z parafiami Kościoła rzymskokatolickiego, największego właściciela ziemskiego, były one najczęściej kilkakrotnie mniejsze ${ }^{57}$. Jedynie biskupstwa miały uposażenie większych rozmiarów ${ }^{58}$. Znaczną część dochodu parochowie uzyskiwali na drodze prawa do pobierania od ludności dziesięciny snopowej i pieniężnej (iskopu $)^{59}$, mesznego, stołowego i innych danin, a także opłat za pełnione posługi religijne, zwane iura stolae ${ }^{60}$. To ostatnie świadczenie, ze względu

55 APL, ChKGK, sygn. 110, s. 388.

${ }^{56}$ Parterowa tkanina - wyrób jedwabny o kwiatowym wzorze. Zob. I. Turnau, dz. cyt., s. 133.

${ }^{57} \mathrm{Na}$ całej ziemi chełmskiej cerkwie parafialne w połowie XVII w. posiadały zazwyczaj uposażenie, w skład którego wchodziły 1-2 łany ziemi wolne od podatków oraz daniny od ludności z całego okręgu parafialnego.

${ }^{58}$ Katolicki biskup chełmski w XVII w. miał 3 miasteczka, 9 wsi, a także dochody $\mathrm{z}$ domów w mieście, gdy tymczasem chełmskie biskupstwo unickie dysponowało tylko sześcioma wioskami. Zob.: AGAD, ASK, Dz. I, sygn. 71, k. 69-71, 507-507v.

59 Dziesięcina - podatek pobierany przeważnie w naturze od podwładnych, obejmujący $10 \%$ ich dochodów i przeznaczony na potrzeby świeckie lub kościelne, zwłaszcza na utrzymanie duchowieństwa. Zob.: J. Dudziak, Dziesięcina, w: Encyklopedia katolicka, red. R. Łukaszyk, L. Bieńkowski, E. Gryglewicz, Lublin 1985, t. IV, kol. 600-601. Zob. także: J. Półćwiartek, Z badań nad rola gospodarczo-społeczna plebanii na wsi pańszczyźnianej ziemi przemyskiej i sanockiej w XVI-XIX wieku, Rzeszów 1974, s. 93.

${ }^{60}$ Meszne - rodzaj daniny rocznej, składanej przez parafian proboszczowi $\mathrm{w}$ formie czynszu pieniężnego lub naturze (zapewne zobowiązującej go do odprawiania mszy). Stołowe - rodzaj czynszu płaconego od domów proboszczowi. Zob.: A. Zajda, Nazwy staropolskich powinności feudalnych, danin i opłat (do 1600 r.), Warszawa-Kraków 
na brak unormowania, często powodowało pewne nadużycia, wyrażające się w zbyt dużych opłatach pobieranych przez niektórych kapłanów ${ }^{61}$. Dodatkowo parochowie mogli korzystać ze służebności dworskich w postaci: wolnego wyrębu w lasach (na opał i budowę), łowienia ryb w stawach i rzekach oraz użytkowania pastwisk.

Pierwsze dane o funduszu tej cerkwi pochodzą z 6 marca 1691 roku, kiedy to właściciel wsi - Adam Kazimierz z Mirowa Myszkowski zatwierdził parochowi wcześniejsze nadania:

Pola według dawnych przywilejów, pierwsze od zachodu słońca, które się zwie Tomaszówka, zaczyna się za łąką od granicy śniatyckiej wzdłuż, a kończy pod drogą niewirkowską, a wszerz od granicy niewirkowskiej po chłopskie ćwierci. Drugie za nim na władyczym zaczyna się z łąką od granicy zawalowskiej wzdłuż, a kończy się po chłopskie przymiarki wszerz od granicy kotlickiej aż do niewirkowskiej. Trzecie zwane kliny zaczyna się wzdłuż, od granicy kotlickiej, a kończy się po chłopskie pola około drogi idącej do Czermna wszerz od chłopskich aż do księżego klina. Czwarte za obszarem dworskim, ku zapustowi kotlickiemu, które się zaczyna od gruszek, wzdłuż równo z dolinami, a kończy się po miedzy Waśka Wojcieszka wszerz po chłopskie pola", z innych rzeczy potwierdza wszystko, co dali jego przodkowie, tj.: „wszelkie powinności od poddanych z Duba i Kotlic", zwolnił parochów, ich sługi, diaków od wszelkich powinności. Ponadto zezwolił parochowi brać drzewo na opał z lasu oraz "piwo i gorzałkę na domowe potrzeby gdzie zechce braćc2.

Kolejnych danych o beneficjum cerkiewnym tej parafii dostarcza protokół wizytacji z 1720 roku $^{63}$. Paroch korzystał z 5 kawałków gruntów ornych, 3 sianożęć (łąk) i jednego ogrodu. Pierwszy grunt „niwa z sianożęciem na Władyczu” leżał pomiędzy granicami wsi Niewirków

1979, s. 126, 186. Iskop - danina oddawana w zbożu. Zob.: J. Kość, Słownictwo regionalne w XVII-XVIII-wiecznych księgach miejskich wschodniej Lubelszczyzny, „Studia Językoznawcze" 1988, t. 13, s. 73. Zob. także: M. Karbownik, Ofiary iura stolae na ziemiach polskich w latach 1285-1918, Lublin 1995.

${ }^{61}$ W 1818 r. Komisja Rządowa Wyznań Religijnych i Oświecenia Publicznego wydała taksy wysokości opłat (iura stolae). Ich wysokość była zależna od jednej z trzech klas, na jakie zostali podzieleni parafianie. Z kolei przynależność do klas zależała od majętności wiernego. Zob.: APL, ChKGK, sygn. 604, s. 438-439.

62 Tamże, sygn. 101, k. 51.

${ }^{63}$ Tamże, sygn. 101, k. 51v. 
i Kotlice ${ }^{64}$. Drugi wielkości pół łanu, także z łąką, położony był pod niezidentyfikowaną „choiną niewirkowską”. Kolejna niwa z dolinami i łąką mieściła się pod zapustem kotlickim. Oprócz tego 2 kliny gruntów ornych leżały pod granicą wsi Kotlice. Ponadto paroch miał prawo pobierać dziesięcinę w wysokości pół kopy z ćwierci gruntu. Niewiele informacji na temat uposażenia pozostawił w protokole wizytacji z 1760 roku biskup M. Ryłł ${ }^{65}$. Hierarcha ograniczył się jedynie do stwierdzenia: „Grunty według dawnych wizytacji”, co może oznaczać, że od 1732 roku w tym zakresie nie nastąpiły żadne zmiany.

\section{PLEBANIA I ZABUDOWANIA GOSPODARCZE}

Chociaż nieznana jest data pobudowania plebanii w Dubie, można być pewnym, że miało to miejsce razem $\mathrm{z}$ budową albo zaraz po wybudowaniu cerkwi. Podobnie zapewne przedstawiała się sprawa $\mathrm{z}$ budynkami gospodarskimi. Trudno sobie bowiem wyobrazić brak miejsca zamieszkania dla parocha i jego rodziny. Pierwsze informacje o plebanii czy zabudowaniach gospodarskich w tej wsi pochodzą z 1720 roku $^{66}$. Dokonujący wówczas przeglądu parafii wizytator stwierdził w protokole: „Ogród jeden, na którym cerkiew, plebania i folwarczek stoi”. Taka sama informacja znajduje się w protokole wizytacji z 1732 roku $^{67}$. W związku z tym, że w okresie staropolskim mianem folwarku określano gospodarstwo rolne lub rolno-hodowlane, musiały w nim być budynki gospodarcze ${ }^{68}$.

64 „Niwami” określano dawniej pasy ziemi często o granicach naturalnych w postaci rowów, łąk, lasów. „Niwą” określano także parcele o kształcie wydłużonym, a niezbyt szerokie.

${ }^{65}$ APL, ChKGK, sygn. 110, s. 388.

${ }^{66}$ Tamże, sygn. 101, k. 52.

67 Tamże, sygn. 103, k. 153.

${ }^{68}$ „Każdy w Polszcze folwark czyli dwór, albo jest taki, że w nim sam pan mieszka, albo też, że w nim tylko trzyma jakiego ekonoma. Pierwszy oprócz budynków gospodarskich musi mieć mieszkanie dla pana; drugi obejdzie się bez niego". Zob. Z. Gloger, Encyklopedia staropolska, Warszawa 1985, t. II, s. 161. M. Kamler, Folwark, w: Encyklopedia historii gospodarczej Polski do roku 1945, red. A. Mączak, Warszawa 1981, s. $173-176$. 


\section{DUCHOWIEŃSTWO PARAFII}

Wśród duchowieństwa unickiego do XVIII wieku nie było podziału na proboszczów (plebanów), wikariuszy czy też prebendarzy. Jeżeli w cerkwi znajdował się więcej niż jeden duchowny, to wszyscy na równi sprawowali liturgię, udzielali sakramentów i spełniali inne posługi duchowne. Dopiero po synodzie w Zamościu w 1720 r. przyjął się termin „paroch” na oznaczenie rządcy parafii. Objęcie parafii przez proboszcza wiązało się z uzyskaniem wcześniejszej zgody kolatora, ponieważ prawo nadawania prezenty na beneficjum mieli właściciele dóbr. Należy zaznaczyć, że uzyskanie prezenty kolatorskiej wiązało się z wniesieniem przez kandydata do probostwa stosownej opłaty na rzecz kolatora ${ }^{69}$. Po spełnieniu tych warunków biskup pretendenta instytuował, a wprowadzenia prezbitera na urząd proboszcza dokonywał, w imieniu biskupa, dziekan.

Podstawowym obowiązkiem duchownego, wynikającym ze święceń i nominacji kierującej go do konkretnej parafii, była opieka duszpasterska nad parafianami. Polegała ona na odprawianiu nabożeństw oraz pełnieniu posług religijnych takich, jak: chrzty, śluby, grzebanie zmarłych, spowiedź. Ważnym elementem pracy księdza było nauczanie prawd wiary, które sprowadzało się do niedzielnego i świątecznego odmawiania pacierza oraz katechizacji ludu. Duchowni przygotowywali się do ich wypełniania na dwa sposoby. Pierwotnym sposobem kształcenia kandydatów na duchownych w Cerkwi unickiej było przysposobienie się do obowiązków kapłańskich przy świątyni pod nadzorem miejscowego parocha ${ }^{70}$. Taki sposób kształcenia utrzymał się do połowy XVIII wieku. Oczywiście, były próby zakładania szkół dla alumnów już w XVII wieku, ale - jak w przypadku planu utworzenia Seminarium Misyjnego dla unitów - kończyły się one niepowodzeniem ${ }^{71}$. W związku z tym podniesieniu poziomu wykształcenia

${ }^{69}$ Kolator, collator - patron sprawujący aktualnie opiekę materialną nad cerkwią, posiadający prawo opiniowania kandydatów na proboszczów. Zob.: B.M. Seniuk, dz. cyt., s. 337 .

${ }^{70}$ H. Kołłątaj, Pamiętnik o stanie Kościoła polskiego katolickiego i o wszystkich innych wyznaniach $w$ Polszcze, w: Stan oświecenia $w$ Polsce $w$ ostatnich latach panowania Augusta III (1750-1764), oprac. J. Hulewicz, Wrocław 1953, s. 214.

${ }^{71}$ Więcej zob.: M. Rechowicz, Sprawa Wielkiego Seminarium Misyjnego dla unitów na ziemiach dawnej Polski (1595-1819), Kraków 1984. 
duchowieństwa służyły, tworzone przy klasztorach, szkoły bazyliańskie. Taka placówka powstała na przykład w Chełmie w 1639 roku $^{72}$. Sytuacja w tym zakresie poprawiła się dopiero w drugiej połowie XVIII stulecia, kiedy zaczęto zakładać unickie seminaria. Wówczas to (w 1759 roku) między innymi uruchomiono Unickie Seminarium Diecezjalne w Chełmie, które funkcjonowało do $1833 \mathrm{roku}^{73}$.

Dla badanej parafii ustalono 4 duchownych. O pierwszym z nich Bazylim Szarabkiewiczu - wiadomo tylko, że zmarł przed 20 kwietnia 1715 roku, ponieważ $\mathrm{w}$ tym dniu prezentę na to beneficjum otrzymał Mikołaj Szarabkiewicz ${ }^{74}$. O parochu tym wiadomo, że urodził się około 1693 roku i pochodził z rodziny kapłańskiej, a wcześniej wspomniany Bazyli był zapewne jego ojcem. Nie było to jakieś odosobnione wydarzenie, ponieważ w XVII i XVIII wieku przeważająca część duchownych unickich w Rzeczypospolitej pochodziła z rodzin kapłańskich. Według Ludomira Bieńkowskiego w XVIII stuleciu taki rodowód miało 70-80\% duchownych ${ }^{75}$. Wiadomo także, że prezentę otrzymał od Michała Jordana, wojewody Racławskiego, gdy miał 22 lata, a przed 20 sierpnia 1732 roku uzyskał nominację na dziekana tyszowieckiego. Mikołaj Szarabkiewicz zmarł w wieku około 73 lat, 27 lipca 1766 roku $^{76}$. Po jego śmierci prezentę na parocha Duba, 24 września 1767 roku, otrzymał ks. Bazyli Kowaszewicz $^{77}$. Z powyższego zapisu wynika, że pomiędzy śmiercią Szarabkiewicza, a nominacją Kowaszewicza upłynął rok. Można zatem mieć pewność, że w tym czasie parafią zarządzał administrator ${ }^{78}$. Ksiądz

${ }^{72}$ M. Rechowicz, Poczatki szkolnictwa teologicznego w Kościele unickim, w: Dzieje teologii katolickiej w Polsce, t. 2, Od Odrodzenia do Oświecenia, cz. 2, Teologia neoscholastyczna i jej rozwój w akademiach i szkołach zakonnych, red. M. Rechowicz, Lublin 1975, s. 579-589. A. Winiarz, Greckokatolickie gimnazjum bazylianów w Chetmie (1639-1769), „Rocznik Chełmski”, 1995, t. 1, s. 31, 38-39.

73 Szerzej zob.: J. Kania, Unickie Seminarium Diecezjalne $w$ Chetmie $w$ latach 1759-1833, Lublin 1993.

${ }^{74}$ APL, ChKGK, sygn. 103, k. 152v.

${ }^{75}$ L. Bieńkowski, Organizacja Kościoła Wschodniego w Polsce, s. 963.

76 APL, ChKGK, sygn. 103, k. 152v; sygn. 110, s. 388; sygn. 636, s. 831.

77 Tamże, sygn. 636, s. 257.

78 Duchowni, którzy zarządzali parafiami, lecz nie byli ich proboszczami, pełnili funkcje administratorów. Sytuacje takie występowały najczęściej z powodu zgonu duchownego lub dobrowolnej rezygnacji dotychczasowego parocha, związanej z objęciem innego, 
Kowaszewicz zmarł przed 23 marca 1770 roku, ponieważ w tym dniu prezentę na beneficjum w Dubie otrzymał ks. Jan Stankiewicz ${ }^{79}$.

Podstawowym obowiązkiem duszpasterskim było odprawianie nabożeństw cerkiewnych i udzielanie posług religijnych (chrzty, śluby, grzebanie zmarłych, spowiedź). Ważnym elementem pracy księdza było także nauczanie prawd wiary. Sprowadzało się to do niedzielnego, ale także świątecznego odmawiania pacierza i katechizacji ludu. Ponadto do obowiązków parocha należało prowadzenie akt stanu cywilnego, wykonywanie rozporządzeń władz zwierzchnich, a także dawanie wiernym przykładu moralnego prowadzenia się oraz wzorców chrześcijańskiego życia. Z reguły duchowni wypełniali te powinności w sposób prawidłowy, zgodnie z zasadami Cerkwi, chociaż zdarzały się odstępstwa w tym zakresie. Niestety, nie dysponujemy zbyt bogatym materiałem źródłowym, mówiącym o pracy duszpasterskiej księży parafii Dubie. Pierwsze, a zarazem i ostatnie dane w tym zakresie pochodzą z dekretu wizytacji z 1760 roku $^{80}$. Odnotowano tam, że pleban Mikołaj Szarabkiewicz studiował z wiernymi „naukę duchową co święta i niedziele po mszy, a katechizm po obiedzie". Jak wykazała wizytacja, nie wszyscy z tych nauk korzystali, skoro wizytujący parafię pod karą kanoniczną zabronił parochowi udzielać ślubu osobom „nieumiejącym przedniejszych artykułów wiary świętej [i] katechizmu".

Pomocnikiem kapłana, który odczytywał Biblię, śpiewał, prowadził chór i świadczył usługi w cerkwi, a często sprawował także funkcję bakałarza, kościelnego, był diak (dziak). Do obowiązków diaków należało również prowadzenie katechizacji i nauczania, ale wypełnianie tych powinności zależało od posiadanej przez nich wiedzy, jak też umiejętności. Najważniejszą jednak powinnością diaka była służba liturgiczna. Diakowie utrzymywali się z funduszu diakowskiego, ustanowionego przez kolatorów lub (jak wspomniano wyżej) ze składek wiernych. Pierwsza, pośrednia informacja o diaku pochodzi z 1698 roku, kiedy to A.K. Myszkowski,

bogatszego beneficjum albo z powodu choroby lub podeszłego wieku, uniemożliwiającego wypełnianie obowiązków duszpasterskich. Zob.: M. Trojanowska, Dokumenty prezent na unickie beneficja parafialne w XVII i XVIII wieku, „Wschodni Rocznik Humanistyczny” 2004, t. 1, s. 325-355.

79 APL, ChKGK, sygn. 636, s. 294.

80 Tamże, sygn. 110, s. 389. 
potwierdzając fundusz cerkwi, z wszelkich powinności zwolnił także diaków tej cerkwi ${ }^{81}$. Co prawda, ujawnione źródła nie wspominają o osobie diaka, ale trudno sobie wyobrazić, żeby przez cały czas funkcjonowania parafii w tej wsi nie było chociaż w niektórych okresach tego sługi cerkiewnego. Podobnie nieznane są obowiązki, jakie miał on do spełnienia, ale można się spodziewać, że nie różniły się zbytnio od obowiązków diaka w pobliskich Tyszowcach ${ }^{82}$.

\section{WIERNI}

Pierwsze dane o unitach w Dubie pochodzą dopiero z XVIII-wiecznych protokołów wizytacji tej parafii. Niestety, w pierwszym tego typu źródle - protokole wizytacji z 1720 roku - wizytator ograniczył się jedynie do stwierdzenia, że parafię stanowili unici dwóch wsi - Duba i Kotlic ${ }^{83}$. Takie same dane wymienione są w protokole wizytacji z 1732 roku $^{84}$. Kolejne źródło, a więc protokół wizytacji z 1760 roku, zawiera zdecydowanie dokładniejsze dane. Dokonujący tej wizytacji biskup M. Ryłło zanotował, że w parafii było ok. 200 „sposobnych do spowiedzi” ${ }^{85}$. Taki wykaz wiernych nie pozwala na określenie liczby parafian, ale może dostarczyć podstawowych informacji o stanie i dynamice zaludnienia parafii, a także nieco bliżej przedstawić jej strukturę demograficzną. Mając tego typu dane i chcąc oszacować ogólną liczbę wiernych, należy (za Cezarym

81 Tamże, sygn. 103, k. 152.

${ }^{82}$ Dokładny zakres obowiązków diaka w Tyszowcach jest znany dzięki raportowi dziekana tyszowieckiego do biskupa chełmskiego z 6 czerwca 1855 roku. Zgodnie z tym raportem obowiązkiem diaka było branie udziału we wszystkich nabożeństwach oraz chrztach i ślubach. Diak towarzyszył parochowi w drodze do chorego z Panem Bogiem i z ostatnim namaszczeniem, a także w odprowadzeniu zmarłego na cmentarz. Oprócz tego należało do niego utrzymanie w ładzie i porządku zakrystii cerkiewnej, ołtarzy oraz wszelkich sprzętów. Ponadto miał wszelkie rozporządzenia zarówno władz duchownych, jak i rządowych jako kurier roznosić. Dodatkowo, tam gdzie nie było funduszu na dziada (pałamarza), obowiązkiem diaka było dzwonienie na pacierz rano i wieczorem, oraz dzwonienie podczas pogrzebu. Zob.: Tamże, sygn. 1187, k. 100.

83 APL, ChKGK, sygn. 101, k. 52.

${ }^{84}$ Tamże, sygn. 103, k. 153.

85 Tamże, sygn. 110, s. 388. 
Kuklo) do uprawnionych do przyjmowania komunii świętej doliczyć co najmniej 25\% wiernych, które stanowiły dzieci młodsze ${ }^{86}$. W związku z tym, posiadając dane, że w 1760 roku sakramenty przyjmowało kolejno 200 wiernych, po dodaniu do tej wartości $25 \%$ wiernych „niekomunikujących", możemy stwierdzić, że parafię zamieszkiwało około 250 osób.

Jednym z najistotniejszych aspektów charakterystyki społeczności parafialnej pozostaje zagadnienie kształtowania się wierzeń i poziomu religijnego uświadomienia. Z przykrością należy stwierdzić, że w przypadku parafii Dub występuje niedostatek źródeł, które pozwoliłyby na określenie poglądów religijnych tamtejszej wspólnoty. Te dostępne nie pozwalają na zbyt daleko idące wnioski, uogólnienia. Pierwsza tego typu pośrednia informacja pochodzi z dekretu powizytacyjnego z 1760 roku, która pozwala wnioskować, że niektórzy wierni nie znali podstaw wiary, ponieważ wizytator (biskup M. Ryłło) dał polecenie parochowi, że: „nieumiejącym przedniejszych artykułów wiary i katechizmu osobom ślubu dawać nie powinien" ${ }^{87}$.

\section{ZAKOŃCZENIE}

Niestety, ze względu na niedostatek źródeł z XVII stulecia, funkcjonowanie parafii p.w. św. Mikołaja w Dubie dotychczas znamy głównie z okresu XVIII wieku. Z tego względu można się jedynie domyślać, że ta parafia unicka, podobnie jak inne, w ciągu pierwszych lat istnienia otrzymała niezbędne podstawy ekonomiczne i wyposażenie do wypełniania wymaganych obrzędów. Zapewne paramenty liturgiczne zmieniały się oraz były uzupełniane przez cały okres funkcjonowania parafii.

Niewiele wiadomo na temat warunków mieszkaniowych parocha, źródła bardzo lakonicznie wspominają o tym tylko dwukrotnie. Podobnie przedstawia się sytuacja w przypadku budynków gospodarczych. Także dane dotyczące liczby wiernych są bardzo ubogie. Określenie liczby parafian jest szczególnie trudne dla XVIII stulecia, kiedy to wizytatorzy nie badali szczegółowo tego zjawiska, kontentując się jedynie pobieżnymi

\footnotetext{
${ }^{86}$ C. Kuklo, Demografia Rzeczypospolitej przedrozbiorowej, Warszawa 2009, s. 74.

${ }^{87}$ APL, ChKGK, sygn. 110, s. 389.
} 
wyliczeniami. Podobnie przedstawia się sytuacja w zakresie obsady cerkwi, gdyż ustalono tylko nazwiska czterech duchownych.

Streszczenie. Z dziejów dekanatu unickiego w Tyszowcach. Parafia p.w. św. Mikołaja w Dubie w XVIII wieku Dub, siedziba parafii unickiej p.w. św. Mikołaja, ma co najmniej XIV-wieczne korzenie. Wieś lokowana była na obszarze, który pierwotnie podlegał strukturom Kościoła greckiego (prawosławnego), a po włączeniu Rusi Czerwonej do Korony także Kościoła łacińskiego. Z tego też względu Dub zamieszkiwali zarówno wyznawcy obrządku wschodniego (najpierw prawosławni, później unici), jak i łacińskiego. W związku z tym we wsi funkcjonowała parafia prawosławna, po unii greckokatolicka oraz lacińska.

Parafia unicka w Dubie była wspólnotą obejmująca dwie wsie (Dub i Kotlice), podległą najpierw dekanatowi tyszowieckiemu, a następnie grabowieckiemu. Ustanie działalności parafii unickiej w Dubie nastąpiło w 1875 roku, wraz z likwidacją unii na obszarze byłego Królestwa Polskiego.

Słowa kluczowe: Dub; Kotlice; parafia; cerkiew; uposażenie; paroch; unici; paramenty; utensylia.

Abstract. The history of the Uniate Deanery of Tyszowce. St. Nicholas Uniate parish in Dub in the $18^{\text {th }}$ century. Dub, the seat of the St. Nicholas Uniate parish, dates back to at least the $14^{\text {th }}$ century. This country village was situated in the region that originally was subject to the structure of Greek Orthodox Church (Eastern Catholic Church), however, once Red Ruthenia had been incorporated into the Kingdom of Poland, it also came under the influence of Latin Catholic Church. Therefore, the inhabitants of Dub followed either Eastern or Latin Catholic Church liturgical rites. The first parish was the Eastern Orthodox parish, then after the Union of Brest it became the Uniate and the Latin one.

The Uniate parish in Dub covered two villages: Dub and Kotlice, which first belonged to the Deanery of Tyszowce and then the Deanery of Grabowiec. The parish ceased to exist after 1875 due to the abolishment of the union in the territory of the former Kingdom of Poland.

Keywords: Dub; Kotlice; parish; Eastern Catholic Church; endowment; paroch (parish priest); paraments; utensils. 